\title{
Aktivitas Anti Bakteri Daun Sirih: Uji Ekstrak KHM (Kadar Hambat Minimum) dan KBM (Kadar Bakterisidal Minimum)
}

\author{
Antibacterial Activity of Betel Leaves: Test of MIC Extract (Minimum \\ Inhibitory Concentration) and MBC (Minimum Bactericidal Concentration)
}
Yolla Arinda Nur Fitriana ${ }^{1}$, Vita Arfiana Nurul Fatimah ${ }^{2}$, Ardhista Shabrina Fitri $^{3}$

${ }^{I}$ Teknologi Pangan - Universitas Ahmad Dahlan Yogyakarta, Indonesia

${ }^{2}$ Fakultas Kedokteran - Universitas Gadjah Mada Yogyakarta, Indonesia

${ }^{3}$ Farmasi - Universitas Muhammadiyah Purwokerto, Indonesia

${ }^{1}$ yolla.anf@gmail.com

2vita.arfiana@gmail.com

3ardhista.fitri@ump.ac.id

\begin{abstract}
ABSTRAK
Daun sirih yang sering dijumpai di pekarangan dapat digunakan sebagai antibakteri karena mengandung 4,2\% minyak atsiri yang sebagian besar terdiri dari beterfenol yang merupakan isomer euganol allylpyrocatechine, cineol metil euganol, caryophyllen, karikol, kavibekol, estragol, dan terpinen. Dalam penelitian ini dilakukan uji ekstrak daun sirih untuk mengetahui nilai KHM (Kadar Hambat Minimum) dan KBM (Kadar Bakterisidal Minimum) terbaik menggunakan bakteri B.subtilis dan E.coli yang telah diuji sensitivitasnya terhadap antibiotik kloramfenikol, vankomisin, dan siprofolksasin. Metode yang digunakan adalah dilusi dan difusi. Metode dilusi digunakan untuk mengukur KHM dan KBM, sedangkan metode difusi digunakan untuk menentukan sensitivitas bakteri uji terhadap antibiotik. Hasil dari penelitian ini menunjukkan bahwa KHM dan KBM terbaik yang diperoleh dari ekstrak daun sirih secara berurutan yaitu $6.25 \%$ dan 50\%. Sensitivitas bakteri uji B.subtilis dan E.coli yang digunakan terhadap antibiotik kloramfenikol, vankomisin, dan siprofloksasin adalah suseptibel atau rentan.
\end{abstract}

Kata-kata kunci: daun sirih, KHM, KBM, sensitivitas bakteri.

\section{ABSTRACT}

Betel leaf which is often found in the yard can be used as antibacterial because it contains $4.2 \%$ volatile oil. It mostly contains of beterphenol which is an isomer of eugenol allylpyrocatechine, cineol methyl euganol, caryophyllene, caricole, cavibechole, estragol, and terpinen. This research was conducted to determine the best MIC (Minimum Inhibitory Concentration) and MBC (Minimum Bactericidal Concentration) values of betel leaf extract using B.subtilis and E.coli bacteria which had been tested for sensitivity towards chloramphenicol, vancomycin, and ciprofloxacin antibiotics. It used dilution and diffusion method. Dilution method was utilized to measure the MIC and $M B C$, while diffusion method was used to determine the sensitivity of the bacteria to antimicrobial agents. Results of this study showed that the best MIC and MBC obtained from betel leaf extract was $6.25 \%$ and $50 \%$ respectively. Sensitivity of B.subtilis and E.coli bacteria to chloramphenicol, vancomycin, and ciprofloxacin antibiotics are susceptible.

Key words: betel leaf, MIC, MBC, bacterial sensitivity. 


\section{PENDAHULUAN}

Antibiotik sebagai sebuah senyawa yang dihasilkan oleh mikroorganisme, pada konsentrasi rendah dapat memusnahkan atau menghambat pertumbuhan mikroorganisme lain. Pengujian potensi antibiotik dilakukan untuk memberikan jaminan bahwa kualitas dan mutu antibiotik yang digunakan dalam pengobatan memenuhi persyaratan yang telah ditentukan (Radji and Manurung, 2010). Antibiotik digunakan untuk membasmi mikroba penyebab terjadinya infeksi. Gejala infeksi terjadi akibat gangguan langsung oleh mikroba dan berbagai zat toksik yang dihasilkan mikroba. Antibiotik yang digunakan untuk membasmi mikroba penyebab penyakit pada manusia, harus memiliki sifat toksik selektif. Artinya, antibiotik harus bersifat toksik untuk mikroba, tetapi relatif tidak toksik untuk hospes atau inang. Toksisitas selektif tergantung kepada struktur yang dimiliki sel bakteri dan manusia. Dinding bakteri yang tidak dimiliki oleh sel manusia membuat antibiotik dengan mekanisme kegiatan pada dinding sel bakteri mempunyai toksisitas selektif relatif tinggi (Ganiswara, 1995).

Pada umumnya, pengujian potensi antobiotik secara mikrobiologi dilakukan dengan menggunakan 2 metode, yaitu turbidimetri dan lempeng silinder atau difusi agar. Prinsip metode turbidimetri adalah berdasarkan hambatan pertumbuhan biakan mikroorganisme dalam media cair yang mengandung larutan antibiotik, sedangkan prinsip metode lempeng silinder atau difusi agar adalah membandingkan zona hambatan pertumbuhan mikroorganisme uji oleh dosis senyawa antibiotik yang diuji terhadap zona hambatan oleh dosis antibiotik baku pembanding pada media lempeng agar (Jawetz et al., 2001). Selain itu, metode difusi digunakan dalam uji sensitivitas bakteri. Metode tersebut dilakukan dengan cara mengamati daya hambat pertumbuhan mikroorganisme oleh ekstrak yang diketahui dari daerah di sekitar kertas cakram (paper disc) yang tidak ditumbuhi oleh mikroorganisme. Zona hambatan pertumbuhan inilah yang menunjukkan sensitivitas bakteri terhadap bahan anti bakteri.

Dalam artikel ini, dibahas 3 jenis antibiotik yaitu kloramfenikol, vankomisin, dan siprofloksasin dengan sensitivitas sebagaimana ditampilkan pada Tabel 1 (Marianti, 2017). Kloramfenikol adalah antibiotik untuk mengatasi infeksi bakteri serius yang bekerja dengan cara membunuh bakteri yang menjangkit di dalam tubuh dan mencegahnya tumbuh kembali. Vankomisin merupakan antibiotik yang digunakan untuk mengobati infeksi usus, seperti diare, nyeri perut, dan radang usus. Obat ini tidak dapat diserap oleh tubuh dan tidak dapat digunakan untuk pengobatan infeksi bakteri pada organ tubuh lainnya. Sementara itu, siprofloksasin adalah antibiotik yang digunakan untuk menangani berbagai jenis infeksi bakteri, seperti infeksi saluran kemih, saluran pencernaan, saluran pernapasan, dan mata. Jenis obat ini bekerja dengan cara membunuh atau mencegah perkembangan bakteri.

Tabel 1. Sensitivitas Antibiotik

\begin{tabular}{clccc}
\hline No. & Antibiotik & Resistant & Intermediete & Susceptible \\
\hline 1 & Chloramphenicol & $<12$ & $13-16$ & $>=17$ \\
2 & Vancomycin & & & $>15$ \\
3 & Ciprofloxacin & $<15$ & $16-20$ & $>=21$ \\
\hline
\end{tabular}

Daun sirih yang banyak ditemukan di lahan atau pekarangan, dapat digunakan sebagai antibakteri karena mengandung 4,2\% minyak atsiri. Minyak tersebut sebagian besar terdiri atas beterfenol yang merupakan isomer euganol allypyrocatechine, cineol metil euganol, caryophyllen, karikol, kavibekol, estragol, dan terpinen (Sastroamidjojo, 1997). Berdasarkan hal tersebut, penelitian ini bertujuan untuk mengetahui nilai KHM (Kadar Hambat Minimum) dan KBM (Kadar Bakterisidal Minimum) terbaik dari uji 
ekstrak infusa daun sirih terhadap bakteri B.subtilis dan E.coli. Sensitivitas bakteri B.subtilis dan E.coli yang digunakan diuji terhadap antibiotik kloramfenikol, vankomisin, dan siprofloksasin.

\section{METODE}

\section{A. Alat dan Bahan}

- Petridish steril

- Tabung reaksi steril

- Aquades steril

- Media MacConkey

- Rak tabung reaksi

- Bunsen

- Inkubator

- Label

- Media MHA

- Antibiotik Vankomisin

- Cotton swab

- Tissue

- Blank dish (kontrol)

- Kultur bakteri yang ditumbuhkan dalam media cair (BHI) umur 24-48 jam (E.coli dan B.subtilis)

\section{B. Langkah Uji}

1. Disiapkan tabung reaksi yang sudah disterilkan dan diberi label I, II, III, IV, V, VI, $\mathrm{Km}, \mathrm{Ks}, \mathrm{Kp}, \mathrm{Ke}$, masing-masing tabung diisi $1 \mathrm{ml}$ medium aquadest kecuali tabung I dan kontrol.

2. Tabung I diisi filtrat dengan konsentrasi $50 \%$ sebanyak $2 \mathrm{ml}$, diambil dari tabung I sebanyak $1 \mathrm{ml}$ dimasukkan ke dalam tabung II (konsentrasi 25\%).

3. Tabung II diambil $1 \mathrm{ml}$, dimasukkan ke dalam tabung III (konsentrasi 12,5\%).

4. Tabung III diambil $1 \mathrm{ml}$, dimasukkan ke dalam tabung IV (konsentrasi 6,25\%).

5. Tabung IV diambil $1 \mathrm{ml}$, dimasukkan ke dalam tabung V (konsentrasi 3,125\%).

6. Tabung V diambil $1 \mathrm{ml}$, dimasukkan ke dalam tabung VI (konsentrasi 1,5625\%).

7. Tabung VI diambil $1 \mathrm{ml}$ dan dibuang.

8. Tabung Ke diisi $1 \mathrm{ml}$ medium uji dan $1 \mathrm{ml}$ ekstrak.

9. Tabung Km diisi $2 \mathrm{ml}$ medium uji.

10.Tabung Kp diisi 1 medium uji dan $1 \mathrm{ml}$ aquadest.

11.Tabung Ks diisi $2 \mathrm{ml}$ suspensi bakteri.

12. Semua tabung ditambah $1 \mathrm{ml}$ suspense bakteri, kecuali tabung kontrol, kemudian diinkubasi pada suhu $37 \mathrm{oC}$ selama 24 jam.

13.Dari tabung II - VI diambil sampel menggunakan cotton swab untuk dioleskan pada media MacConkey yang telah diberi label sesuai konsentrasi ekstrak infusa daun sirih.

14.KHM ditentukan dengan mengamati kekeruhan dan kejernihan dari masing-masing medium uji yang telah diinkubasi dan dibandingkan dengan larutan kontrol media. Konsentrasi paling rendah yang menunjukkan penghambatan pertumbuhan bakteri ditandai dengan jernihnya medium uji. 
15.KBM ditentukan dengan pengamatan ada tidaknya pertumbuhan bakteri dalam media agar setelah diinkubasi. Konsentrasi terendah yang memperlihatkan kematian bakteri (tidak ada pertumbuhan) merupakan nilai KBM.

\section{HASIL DAN PEMBAHASAN}

\section{A. Metode Dilusi}

Metode dilusi dibagi menjadi 2, yaitu dilusi cair dan padat. Metode dilusi cair digunakan untuk mengukur KHM (kadar hambat minimum) sementara metode dilusi padat digunakan untuk menentukan KBM (kadar bakterisidal minimum). Cara yang dilakukan pada metode dilusi cair adalah dengan membuat seri pengenceran agen antimikroba pada medium cair yang ditambahkan dengan mikroba uji. Metode dilusi padat dilakukan dengan menginokulasi mikroba uji pada media agar yang mengandung agen antimikroba. Keuntungan metode dilusi ini adalah satu konsentrasi agen antimikroba yang diuji dapat digunakan untuk menguji beberapa mikroba uji (Pratiwi, 2008). Hasil pengujian terhadap ekstrak daun sirih disajikan pada Gambar $1-3$ dan Tabel $2-7$.

\section{B. Metode Difusi}

Metode difusi digunakan untuk menentukan sensitivitas mikroba uji terhadap agen antimikroba. Metode ini dilakukan dengan menggunakan kertas cakram. Ke dalam media agar yang telah diinokulasi dengan bakteri dimasukkan kertas cakram dan diisi dengan senyawa uji. Area jernih pada permukaan media agar mengindikasikan adanya hambatan pertumbuhan mikroorganisme oleh agen antimikroba. Kelebihan metode difusi ini adalah mudah dilakukan karena tidak memiliki alat khusus dan mencakup fleksibilitas yang lebih besar dalam memilih obat yang akan diperiksa (Katrin et al., 2015).

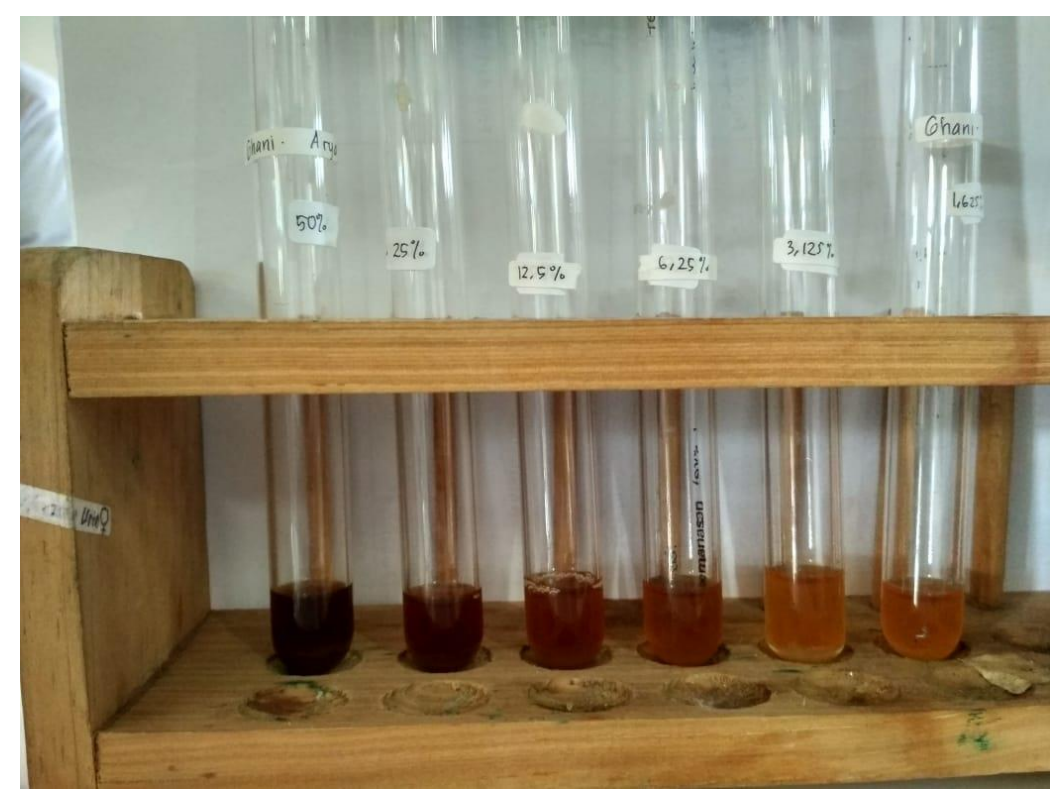

Gambar 1. Hasil KHM ekstrak infusa daun sirih 


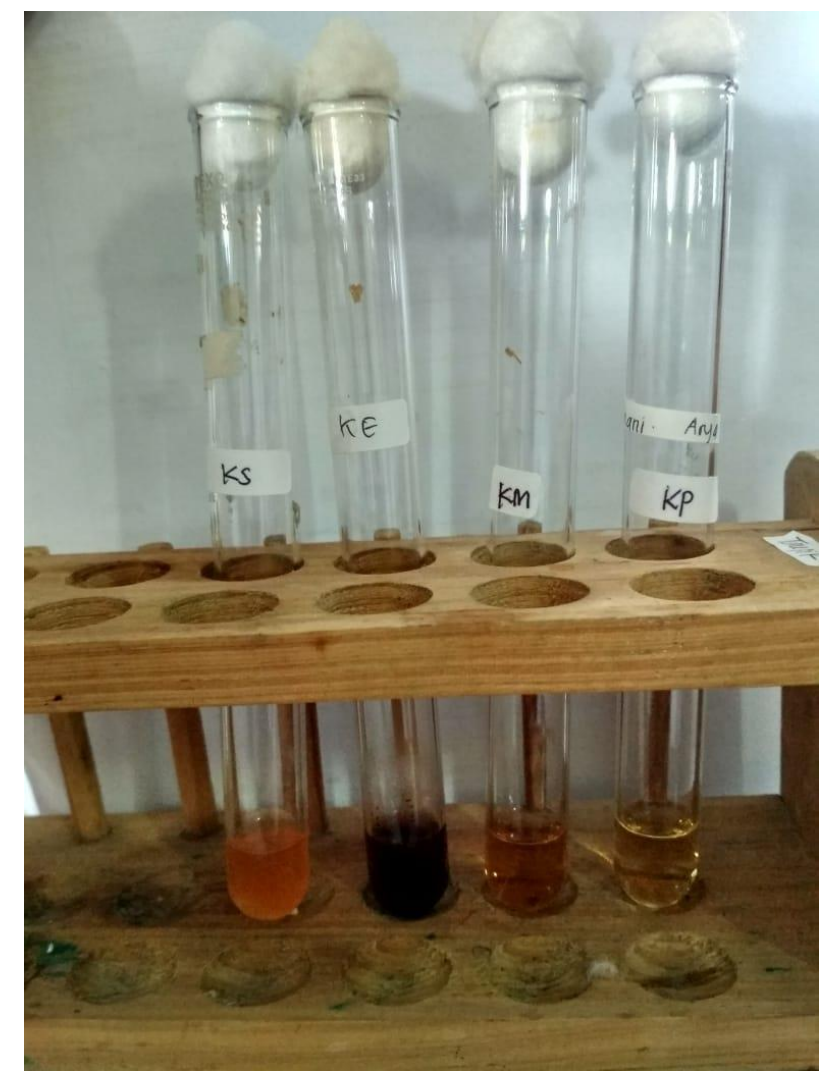

Gambar 2. Hasil KHM pada tabung kontrol

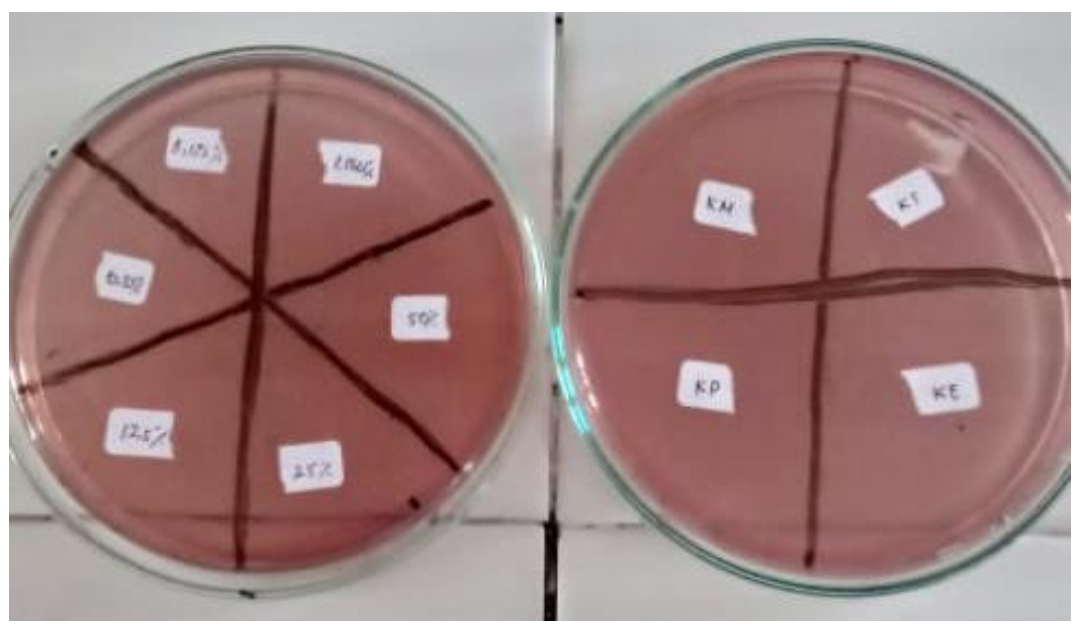

Gambar 3. Hasil KBM ekstrak infusa daun sirih dan kontrol

Tabel 2. Hasil KHM ekstrak infusa daun sirih

\begin{tabular}{ccc}
\hline No. & Tabung & Keterangan \\
\hline 1 & $50 \%$ & keruh \\
2 & $25 \%$ & Keruh bergelembung \\
3 & $12,5 \%$ & Keruh bergelembung \\
4 & $6,25 \%$ & Jernih $\rightarrow$ KHM \\
5 & $3,125 \%$ & Jernih \\
6 & $1,5625 \%$ & Jernih \\
\hline
\end{tabular}


Tabel 3. Hasil pengamatan uji antibiotik daun sirih KHM pada tabung kontrol

\begin{tabular}{ccc}
\hline No. & Tabung & Keterangan \\
\hline 1 & Kontrol pelarut & Tidak tumbuh \\
2 & Kontrol suspensi & Tumbuh mikroba \\
3 & Kontrol media & Tidak tumbuh \\
4 & Kontrol ekstrak & Tidak tumbuh \\
\hline
\end{tabular}

Tabel 4. Hasil pengamatan KBM pada perlakuan media MacConkey (daun sirih)

\begin{tabular}{ccc}
\hline No. & Tabung & Keterangan \\
\hline 1 & $50 \%$ & Tidak tumbuh $\rightarrow$ KBM \\
2 & $25 \%$ & Tumbuh mikroba \\
3 & $12,5 \%$ & Tidak tumbuh \\
4 & $6,25 \%$ & Tidak tumbuh \\
5 & $3,125 \%$ & Tidak tumbuh \\
6 & $1,5625 \%$ & Tumbuh mikroba \\
\hline
\end{tabular}

Tabel 5. Hasil pengamatan KBM pada kontrol media MacConkey (daun sirih)

\begin{tabular}{ccc}
\hline No. & Tabung & Keterangan \\
\hline 1 & Kontrol pelarut & Tumbuh mikroba \\
2 & Kontrol suspensi & Tumbuh mikroba \\
3 & Kontrol media & Tumbuh mikroba \\
4 & Kontrol ekstrak & Tumbuh mikroba \\
\hline
\end{tabular}

Metode dilusi digunakan untuk menentukan KHM dan KBM dari obat antimikroba. Prinsip dari metode dilusi ini adalah menggunakan satu seri tabung reaksi yang diisi media cair dan sel bakteri uji B.subtilis dan E.coli. KHM obat ditunjukkan dari konsentrasi terendah antibiotik pada tabung dengan hasil biakan yang mulai tampak jernih (tidak ada pertumbuhan mikroba). Konsentrasi terendah obat pada biakan padat yang ditunjukkan dengan tidak adanya pertumbuhan koloni mikroba adalah KBM dari obat terhadap bakteri uji.

Percobaan ini menggunakan antibiotik dari ekstrak infusa daun sirih. Dari Tabel 2 diperoleh nilai KHM pada ekstrak sebesar 6,25\% dan nilai ini adalah yang terbaik yang dapat membunuh bakteri E.coli. Hal ini ditandai dengan hasil perlakuan yang jernih. Pada Tabel 4 diperoleh nilai KBM terbaik pada ekstrak daun sirih yaitu 50\%. Menurut Sastroamidjojo (1997), daun sirih mengandung 4,2\% minyak atsiri yang sebagian besar terdiri dari beterphenol yang dapat digunakan sebagai antibakteri.

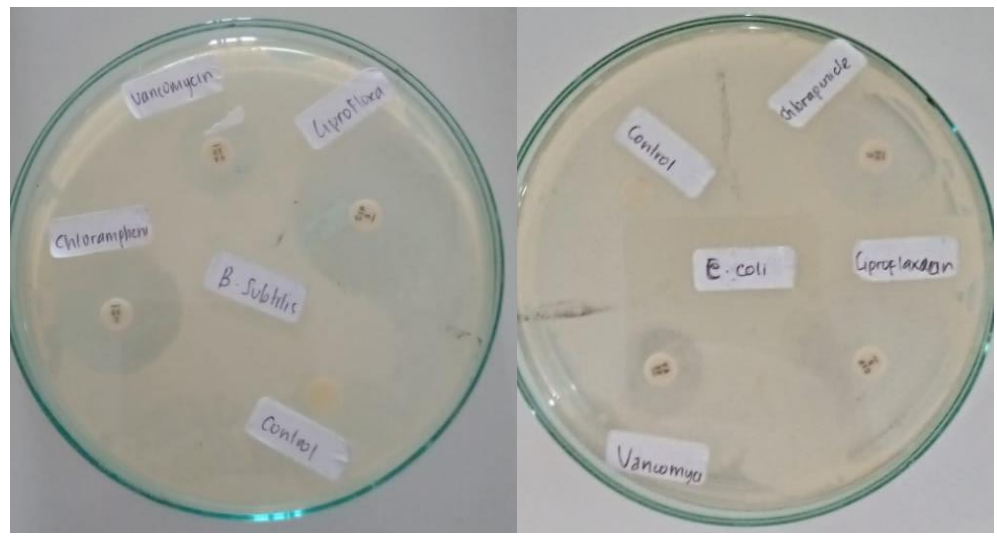

Gambar 4. Sensitivitas bakteri uji B.subtilis dan E.coli terhadap antibiotik kloramfenikol, vankomisin, siprofloksasin, dan kontrol 
Tabel 6. Hasil pengamatan aktivitas antibiotik pada bakteri Bacilus subtilis

\begin{tabular}{cccc}
\hline No & Antibiotik & Diameter & Keterangan \\
\hline 1 & Kontrol & - & - \\
2 & Chloramphenicol & $25 \mathrm{~mm}$ & susceptible \\
3 & Vancomycin & $17 \mathrm{~mm}$ & Susceptible \\
4 & Ciprofloxacin & $31 \mathrm{~mm}$ & Susceptible \\
\hline
\end{tabular}

Tabel 7. Hasil pengamatan aktivitas antibiotik pada bakteri E.coli

\begin{tabular}{cccc}
\hline No & Antibiotik & Diameter & Keterangan \\
\hline 1 & Kontrol & - & - \\
2 & Chloramphenicol & $23 \mathrm{~mm}$ & susceptible \\
3 & Vancomycin & $18 \mathrm{~mm}$ & Susceptible \\
4 & Ciprofloxacin & $30 \mathrm{~mm}$ & Susceptible \\
\hline
\end{tabular}

Gambar 4 dan Tabel 6-7 merupakan hasil uji sensitivitas bakteri uji B.subtilis dan E.coli yang digunakan terhadap antibiotik standar. Antibiotik standar yang digunakan adalah kloramfenikol, vankomisin, dan siprofloksasin. Metode yang digunakan dalam uji aktivitas antibiotik ini adalah metode difusi. Pada metode ini, apabila bakteri uji sensitif terhadap antibiotik, akan terbentuk area jernih di sekitar antibiotik yang ditanam pada media tempat bakteri uji diinokulasi.

Pada metode difusi ini, proses inokulasi dilakukan menggunakan cotton swab. Cotton swab ini berfungsi untuk mengambil mikroba pada tabung reaksi agar tidak terkontaminasi dan dapat meratakan mikroba pada saat diletakkan di media. Hasil pengukuran diameter area jernih yang diperoleh dari percobaan difusi ini menunjukkan bahwa bakteri uji B.subtilis dan E.coli yang yang digunakan dalam uji ekstrak infusa daun sirih suseptibel atau rentan terhadap antibiotik kloramfenikol, vankomisin, siprofloksasin.

\section{KESIMPULAN}

Dari penelitian ini dapat disimpulkan bahwa KHM dan KBM terbaik ekstrak infusa daun sirih terhadap bakteri uji B.subtilis dan E.coli secara berurutan adalah $6.25 \%$ dan $50 \%$. Bakteri uji B.subtilis dan E.coli yang digunakan menunjukkan kerentanan terhadap antibiotik kloramfenikol, vankomisin, dan siprofloksasin.

\section{DAFTAR PUSTAKA}

Ganiswara, S.G., 1995. Farmakologi dan Terapi 4th ed., Jakarta: Balai Penerbit FKUI.

Jawetz, E., Melnick, J.L. and Adelberg, E.A., 2001. Mikrobiologi untuk Profesi Kesehatan (Review of Medical Mikrobiology), Jakarta: Kedokteran EGC.

Katrin, D., Idiawati, N. and Sitorus, B., 2015. Uji Aktivitas Antibakteri Dari Ekstrak Daun Malek (Litsea graciae Vidal) Terhadap Bakteri Stapylococcus aureus dan Escherichia coli. Jurnal Kimia Khatulistiwa, 4(1), pp.7-12.

Marianti, 2017. ANTIBIOTIK. Available at: https://www.alodokter.com/antibiotik [Accessed May 26, 2019].

Pratiwi, S.T., 2008. Mikrobiologi Farmasi, Jakarta: Erlangga.

Radji, M. and Manurung, J., 2010. Buku Ajar Mikrobiologi, Panduan Mahasiswa Farmasi dan Kedokteran, Jakarta: Buku kedokteran EGC. 
Sastroamidjojo, S., 1997. Tumbuh-tumbuhan yang dipergunakan sebagai obat asli Indonesia, Jakarta: Dian Rakyat. 